\title{
The Lilly Fellowship Program at Indiana University
}

In an effort to contribute to the solution of the problem of the shortage of trained and experienced rare book librarians, Indiana University established its Lilly Fellowship Program for a three-year experimental period in 1961. Six Fellows, all of whom are now in rare book work, were trained in the program. The program has given all evidences of success, and it is hoped that it can be reestablished on a permanent basis.

$\mathrm{T}$ HE WIDE-SPREAD SHORTAGE of trained library personnel is particularly acute in those areas requiring specialized subject knowledge. Though good reference librarians and catalogers are in short supply, the difficulty of finding a knowledgeable mathematics or music librarian is even greater. Yet in the sciences and in the arts we do have a body of trained personnel who, if they can be attracted to the library profession, can fill these needs. The problem of finding candidates with the requisite background for rare book librarianship is a somewhat different matter for there is no undergraduate training comparable to an $\mathrm{AB}$ in mathematics or music to prepare them for their work. Indeed, in the past, we have had no organized programs for training rare book librarians. We have drawn them from the booktrade and from the ranks of private collectors and printing enthusiasts. They have come to us as self-trained men with a knowledge derived from personal experience rather than formal training. It can be, and frequently has been, argued that there is no background for rare book work comparable to experience in the trade or as a collector-but the fact remains that these sources cannot supply the number

Dr. Byrd is University Librarian at Indiana University, Bloomington. of rare book librarians which are now required. New sources of experience and training must be developed.

Once the Indiana University rare book collection had been transferred to the newly dedicated and opened Lilly library in October 1960, the time was thought appropriate to make a gesture in the direction of the training of rare book librarians. A program was visualized which might alleviate slightly the critical shortage of personnel in this branch of the profession, dramatize the importance of rare books in academic surroundings, and stimulate additional programs of training at other places. Indiana's credentials for this venture were an enthusiastic and experienced staff; fairly representative rare book and manuscript collections; and a new, modern, and attractive physical plant.

The proposed program was described fully to the Lilly Endowment. It was explained as a one-year training course for students who desired to become rare book librarians. It was felt to be in the interest of the profession and was expected to benefit the entire scholarly community. The directors at the Lilly Endowment concluded that the proposal had merit and agreed to finance a program for a three-year experimental period.

In the fall of 1960 announcements of 
the Lilly Fellowships for 1961-62 were released to the library press and all library schools. The qualifications required of applicants were set forth in the announcement: "Any graduate of an accredited library school, under fortyfive years of age, who desires to specialize in rare book librarianship may apply for a fellowship. . . . At the conclusion of the year, Fellows are expected to find employment in rare book divisions of college, university, and public libraries."

There was reason for requesting applicants only from library schools. Their training, though somewhat general in many particulars, enables them to grasp quickly the interrelation and function of a rare book library which is a part of a centralized library system. They have acquired basic skills transferable to any library situation. It has been customary in some circles to rail the library schools for omissions in training, particularly as they relate to rare book librarianship. They should instead be complimented for the excellent preparation they give to students entering library service, rather remarkable preparation when it is considered that this training is given in the short span of two academic semesters.

Some statistical information on the total number of applicants over the three-year period and a few personal observations may be of interest. For the academic year 1961-62 there were twenty-seven applicants from twenty-one different library schools; for 1962-63, twenty-one from fifteen different library schools; in 1963-64, twenty-one from seventeen different library schools. Not all applicants were newly graduated. A few had been in library work for several years.

A careful scrutiny of the applications reveals much on the sociology of contemporary fellowship application. It substantiates a conviction that every academic profession has a ten per cent minority of would-be-permanent graduate students who will apply for anything that promises a year of subsidy at more than modest rates. These among the Lilly applicants listed as a major endowment only "a love for rare books." Ninety per cent of the applicants, however, had excellent academic records and most eloquent recommendations. It was agonizing to choose only two annually from among so many really good candidates.

Beyond academic records, a deciding factor in selecting a Fellow was a previously expressed interest in rare books demonstrated by library school courses, publications, personal collecting activities, or student employment in special collections and rare books.

Six Fellows were trained during the three-year period. The first two Fellows, (1961-62) were Kenneth Nesheim and J. William Matheson. Mr. Nesheim is the assistant librarian, Beinecke library, Yale. Mr. Matheson is chief, rare book department, Washington University, St. Louis. During 1962-63, John Neu and Keith Kern were Fellows. Mr. Neu is now bibliographer for science, University of Wisconsin. Mr. Kern is in the trade in Baltimore. The last two Fellows (1963-64) were G. William Stuart and Richard Ploch. Mr. Stuart is rare book librarian, Cornell University. Mr. Ploch is curator of rare books and special collections, Ohio State University.

Please note that not a single Fellow was retained on the staff of the Indiana University libraries. It was Indiana's unannounced pledge to send them out to seek employment elsewhere; this was true despite the fact that Indiana had need of at least three of the six but refrained from hiring them.

The educational goals of the program of training which the Fellows follow could be expressed in the adage "learn by observation, reflection and by doing." There was envisioned for the Fellows the broadest possible contacts with the management, use, preservation, and acquisition of rare books and manuscripts. Ad- 
ditionally, they were exposed to the antiquarian booktrade and expected to become competent bibliographers, capable of analyzing and describing the anatomy of a book using the scientific methods enunciated by W. W. Gregg and expanded by Fredson Bowers in his Principles of Bibliographical Description.

The program was not designed to train chief rare book librarians, curators, or any particular specialist in the rare book profession. It was hoped rather to familiarize the Fellows with all operations involved in running the Lilly library, a fairly typical rare book operation. They were not compelled to learn, but there was ample opportunity for the inquisitive and the motivated to acquire a large store of information that could be of practical use in any aspect of rare book librarianship.

Theoretically, the Fellows were scheduled to work one-half time in the divisions of Lilly and spend the other half working on special bibliographical projects of their own choice or studying for the afternoon class in bibliography. Here is a sample for 1963-64: July 1-August 17-General observation. Browsing-familiarization with collections. Tour of main and branch libraries on Bloomington campus. August 19-November 15-Acquisitions, cataloging, physical care of rare books (one-half time). November 18February 14-Manuscripts (one-half time). February 17-April 15-Reference desk, work on desiderata lists (one-half time). April 15-June 15-arrange special exhibit (one-half time).

After the initial "getting acquainted" period each section of the schedule was designed to give the Fellows experience in some aspect of rare book work in which they were unlikely to have received training while attending library school. Thus what they were taught about acquisitions, cataloging, and the physical care of rare books bore little resemblance to similarly titled library school courses. The Fellows searched dealers' catalogs and learned something of various booksellers' specialties and standards of description; they learned how to describe variants and bindings when cataloging rare books; and they learned not only how to treat and house precious and fragile pieces but how to handle them as well. The training in manuscripts was felt to be particularly valuable. It is an area almost totally ignored in the training of librarians and one with which every curator of special collections must become familiar. In the three months they spent in the manuscripts division of the Lilly library the Fellows were given opportunity to see how a manuscript collection is organized and cataloged. Finally, as sort of a climax to their training they were expected to plan and mount an exhibit in the Lilly library, a task which allowed them to utilize much of what they had learned in the year.

Emergencies frequently disrupted the schedule. There were collections to unpack, books to move, visitors to guide. There were a few unbookish chores such as taxi driving. Despite best efforts, these unscheduled interruptions were never wholly eliminated.

It was also felt desirable for the Fellows to have at least a passing acquaintance with other rare book collections, private and public, the antiquarian book trade, and at least one attendance at an important book auction. Each year the two Fellows were taken on two extended trips, one to the Chicago area, the other to the East coast. The latter included visits to establishments at New Haven, Boston, New York, Philadelphia, and Washington. On these trips they were given an opportunity to visit with dealers and private collectors. Each time a bookseller called at the Lilly library with his books, the Fellows were invited to inspect, listen, and converse.

The program has proved to be an effective method of training librarians 
for rare book service. The Fellows have not emerged from the program as seasoned veterans, fully qualified rare book librarians, but they have had training not available elsewhere in such a relatively compressed period of time, and this training has given them a good start on the road to rare book librarianship. Indiana University had been the first to admit that its program was not well defined the first year, or the second or

\section{TELETYPEWRITERS . . .}

(Continued from page 286)

experience in interlibrary loans. Everyone wanting an interlibrary loan is in a hurry, and the quicker the library can supply the patron's needs, the happier the patron and the better the library image. In fact, for every use to which teletypewriters are put there are distinct, directly related advantages, as can be seen from a study of any individual case study in this report. The only disadvantage noted was that of cost caused by an increase in toll rates in the United States in 1953. This increase in rates caused several units to discontinue operation; such was the case of the Detroit public library.

Librarians considering the installation of a teletypewriter will naturally need to analyze the requirements of their particular libraries in order to determine which machine applications should be made and what advantages would accrue, and whether these advantages would justify the costs. For instance, in the case of a foreign library with much long distance or international traffic, the use of an optional accessory such as a tape perforator would be desirable, since one of the library's fundamental considerations would be methods of conserving toll costs, which leads to another point. Even in the fifteen existing case studies, little data on costs have been even the third. It was improvised as it proceeded. From this trial and error experience, however, sufficient information was gained to devise a more exacting program in the future. The experimental period financed by the Lilly Endowment expired with the end of the academic year 1963-64. It is hoped that the future will bring financing on a permanent basis.

published. It is an established fact that teletypewriter costs are lower than telephone tolls, but exact figures are difficult to find, and when found are usually out-of-date or invalid because of geographical peculiarities.

That fifteen libraries or library-related organizations have advantageously and successfully used teletypewriters since 1927 would indicate that this type of communication device is fairly well established in library operations. A recent census of the Teletypewriter Exchange Service (TWX) which appeared in Library Journal indicates that the use of this means of data communication is increasing. ${ }^{1}$

It is difficult to predict what the future holds for the teletypewriter and its functions as a library tool. Continued use in its present capacities is probably assured. Research is presently being done by at least one manufacturer in the area of computer and teletypewriter related applications. If these experiments prove to be successful, it could be that the automated libraries of the present and future will continue to find uses for the types of operations which the teletypewriter can perform.

\footnotetext{
${ }^{1}$ James D. Mack, "More Libraries Using Teletype for Interlibrary Loans," Library Journal, LXXXIX (December 15,1964$), 4880$.
} 